\title{
Presamtaler med revmatologiske pasienter ga effektive innleggelser
}

\section{«Fast track»-inspirert revmatologi kan gjøre behandlingsforløpet raskere og forberede pasientene bedre på innleggelse.}

Thomas Berg

Sykepleier og sykepleierstudent i prosjekt

Revmatologisk avdeling, St. Olavs hospital

Eva K. Lyngvær

Seksjonsleder

Revmatologisk avdeling, Klinikk for ortopedi, revmatologi og hudsykdommer, St. Olavs

Hospital

Kjersti Grønning

Førsteamanuensis

Institutt for samfunnsmedisin og sykepleie, Norges teknisk-naturvitenskapelige universitet

Revmatologi

Informasjon

Oppgaveglidning

Sykepleie

Sykepleien 2017105 (64558) (e-64558)

DOI: 10.4220/Sykepleiens.2017.64558

\section{Hovedbudskap}

«Fast-track»-inspirert revmatologi handler om effektiv og god planlegging av elektive innleggelser i Revmatologisk avdeling. Gjennom presamtaler på telefon kan sykepleieren avklare pasientenes forventninger til innleggelsen, innhente nødvendig informasjon fra pasienten og gi informasjon om planlagte prøver og unders $\varnothing$ kelser. Presamtalen kan også bidra til at pasienten blir mer involvert og delaktig i egen behandling. 
«Fast-track»-konseptet ble implementert av den danske kirurgen Henrik Kehlet og har vist seg å gi bedre medisinske resultater, lavere kostnader og kortere liggetid på sykehus (1).

På Revmatologisk avdeling ved St. Olavs Hospital ble det etablert en tverrfaglig arbeidsgruppe som fikk i mandat å unders $\varnothing$ ke hvorvidt det var mulig å implementere prinsippene fra «fast track»-kirurgi-metodologien til et medisinsk revmatologisk behandlingsforløp (2). Elektive innleggelser på revmatologisk avdeling dreier seg ofte om å utrede, behandle med medikamenter eller få stilt en diagnose.

\section{Revmatiske sykdommer}

Utredning av revmatiske sykdommer er ikke alltid like forutsigbart som et kirurgisk eller ortopedisk forløp. Revmatiske sykdommer omfatter blant annet vaskulittsykdommer, bindevevssykdommer (systemisk lupus erythematosus (SLE), Sjögrens syndrom, systemisk sklerose og Mixed Connective Tissue Disease (MCTD) samt kroniske, inflammatoriske leddsykdommer som revmatoid artritt, psoriasisartritt, spondylartritt med perifere artritter og polyartritt (se faktaboks).

\section{Revmatiske sykdommer}

- Vaskulitt: Betennelse i en karvegg.

- Systemisk lupus erythematosus (SLE): «Den røde ulven». Hudsykdom forbundet med indre skader. En kronisk sykdom med blant annet hudutslett, leddplager, nyreforstyrrelser og forandringer av de hvite blodcellene.

- Sjögrens syndrom: Nedsatt utskillelse i tåre- og spyttkjertlene og i neseslimhinnen.

- Systemisk sklerose: Også kalt systemisk sklerodermi. En alvorlig bindevevssykdom som først og fremst rammer de små blodkarene, særlig kapillærene, som tettes igjen. Sykdommen angriper også indre organer, som får fibrotiske forandringer.

- Mixed Connective Tissue Disease (MCTD): Sammensatt bindevevssykdom som rammer hele kroppen.

- Revmatoid artritt: Kronisk leddrevmatisme. En gruppe sykdommer av uklart opphav med en kronisk, inflammatorisk prosess, særlig i leddenes bindevev og brusk, men også i annet støttevev, og med påvirkning på hele kroppen.

- Psoriasisartritt: Psoriasisleddgikt. Inflammatorisk leddsykdom som er assosiert med hudsykdommen psoriasis. 
- Spondylartritt: Betennelse i ryggradens små ledd.

- Polyartritt: Samtidig betennelse i flere ledd.

Kilde: Lindskog BI. Gyldendals store medisinske ordbok. Oslo: Gyldendal Norsk Forlag; 2003

Pasientenes symptomer og plager varierer. For de inflammatoriske leddsykdommene dreier det seg ofte om fysiske funksjonsutfordringer, smerter, stivhet, tretthet, søvnforstyrrelser og sosiale utfordringer $(3,4)$. Symptomene varierer gjennom sykdomsforløpet og påvirker pasientenes dagligdagse aktiviteter, arbeidsevne og livskvalitet (5).

Behandlingen er individuelt tilpasset og inkluderer ulike medikamenter som lindrer symptomer og reduserer sykdomsaktiviteten. Den medikamentelle behandlingen består ofte av ett eller flere preparater av typen sykdomsmodifiserende medikamenter, Disease-Modifying Anti-Rheumatic Drugs (DMARD), i tillegg til ikke-steroide antiinflammatoriske midler, Non-Steroid Anti-Inflammatory Drugs (NSAID) (se faktaboks).

\section{Medikamenter}

- Disease-Modifying Anti-Rheumatic Drugs (DMARD): Samlebetegnelse for sykdomsmodifiserende legemidler som brukes i behandlingen av leddgikt og av og til ved andre inflammatoriske revmatiske sykdommer. DMARD reduserer smerter, stivhet og betennelse, men reduserer også utviklingen av bruskforandringer og bendestruksjon ved leddgikt. Vanligste brukte DMARD er methotrexat.

- Non-Steroid Anti-Inflammatory Drugs (NSAID): Ikke-steroide antiinflammatoriske midler, legemidler. De vanligste er ibuprofen, naproksen, diklofenak og piroxikam.

Kilde: Store medisinske leksikon

\section{Overlege vurderer}

I «fast-track»-inspirert revmatologi blir henvisningen fra fastlegen vurdert av en overlege. Overlegen tar utgangspunkt i en diagnosespesifikk sjekkliste som inneholder et utvalg prøver og undersøkelser som bør vurderes. 
Overlegen krysser av for hvilke unders $\varnothing$ kelser og prøver som skal tas, sekretæren forhåndsbestiller prøvene og

unders $\varnothing$ kelsene, og pasienten blir tildelt en foreløpig dato for innleggelse på det ukentlige inntaksmøtet. Sekretæren sender deretter et brev til pasienten med informasjon om at en sykepleier vil ringe pasienten på et bestemt tidspunkt for å snakke om innleggelsen.

\section{Presamtaler}

Behovet for en presamtale kom frem som et resultat av det tverrfaglige arbeidet i arbeidsgruppen (2). Samtalen kan gjennomføres som en poliklinisk konsultasjon eller på telefon, alt etter pasientens $\varnothing$ nsker og behov. Hensikten med presamtalen er å avklare pasientens forventninger til innleggelsen i tillegg til å gi informasjon, slik at pasienten er best mulig forberedt på innleggelsen (2).

Ifølge helsepersonelloven (6) skal sykepleieren og annet helsepersonell gi pasienten nødvendig informasjon slik at pasienten får innsikt $i$ helsetilstanden sin og innholdet i helsehjelpen (7). I presamtalen informerer sykepleieren om eventuelle forberedelser som må gjøres før innleggelsen eller i forbindelse med aktuelle unders $\varnothing$ kelser.

\section{三 «Behovet for en presamtale kom frem som et resultat av det tverrfaglige arbeidet $i$ arbeidsgruppen.»}

Denne typen informasjon er viktig for at pasientene skal ha mulighet til å samtykke og medvirke i de beslutningene som skal tas. Informasjon kan også bidra til å redusere frykt og engstelse, og pasientene kan føle seg tryggere på at de er godt ivaretatt $(3,4)$.

Den dagen pasienten legges inn, får vedkommende tildelt en skriftlig oversikt med tidspunkt over hvilke prøver, konsultasjoner og undersøkelser som skal gjennomføres.

På den måten unngår pasienten å vente unødig og spekulere på hva som skal skje, og når ting skal skje (2). Med dette som bakteppe ville vi unders $\varnothing$ ke sykepleiernes opplevelser med å gjennomføre presamtaler i det «fast-track»-inspirerte revmatologiske behandlingsforløpet. 


\section{Metode}

Dette fagutviklingsprosjektet var et samarbeid mellom daværende Institutt for sykepleievitenskap, Norges teknisknaturvitenskapelige universitet (NTNU), og Revmatologisk avdeling, St. Olavs Hospital. Revmatologisk avdeling samarbeider med bachelorutdanningen i sykepleie ved NTNU om flere prosjekter for å utvikle sykepleiefaget og øke oppmerksomheten rundt kunnskapsbasert praksis i helsetjenesten.

Som et ledd i dette samarbeidet kan sykepleierstudenter delta i prosjekter i forbindelse med bacheloroppgaven i sykepleie. Denne artikkelen baserer seg på prosjektet «'Fast-track'inspirert revmatologi» og omhandler hvordan sykepleierne opplevde det å gjennomføre presamtaler før elektive innleggelser.

For denne studien utarbeidet vi et enkelt spørreskjema til sykepleierne ved Revmatologisk avdeling. Spørreskjemaet tok utgangspunkt i sjekklistene som sykepleierne bruker i presamtalen for å innhente og gi informasjon før innleggelsen.

Spørsmålene omhandlet hvordan sykepleierne opplevde det å gi og innhente informasjon, hvorvidt sykepleierne syntes at pasientene hadde blitt mer involvert i egen behandling og hvorvidt sykepleierne følte at de hadde tilstrekkelig faglig kompetanse til å gjennomføre presamtalene. Sykepleierne ble også spurt om hvorvidt presamtalene hadde betydning for kvaliteten på behandlingen.

\section{Resultater}

Seks sykepleiere svarte at de hadde hatt egne presamtaler i det «fast-track»-inspirerte behandlingsforløpet. De fleste sykepleierne svarte at de i stor eller svært stor grad fikk avklart pasientenes forventninger til oppholdet.

Når det gjaldt spørsmålet om hvorvidt sykepleierne opplevde at de fikk gitt nødvendig informasjon til pasienten om hva som var formålet med innleggelsen, planlagte prøver og unders $\varnothing$ kelser og avdelingens rutiner, svarte de fleste at de i stor eller svært stor grad fikk gjort dette (figur 1). 


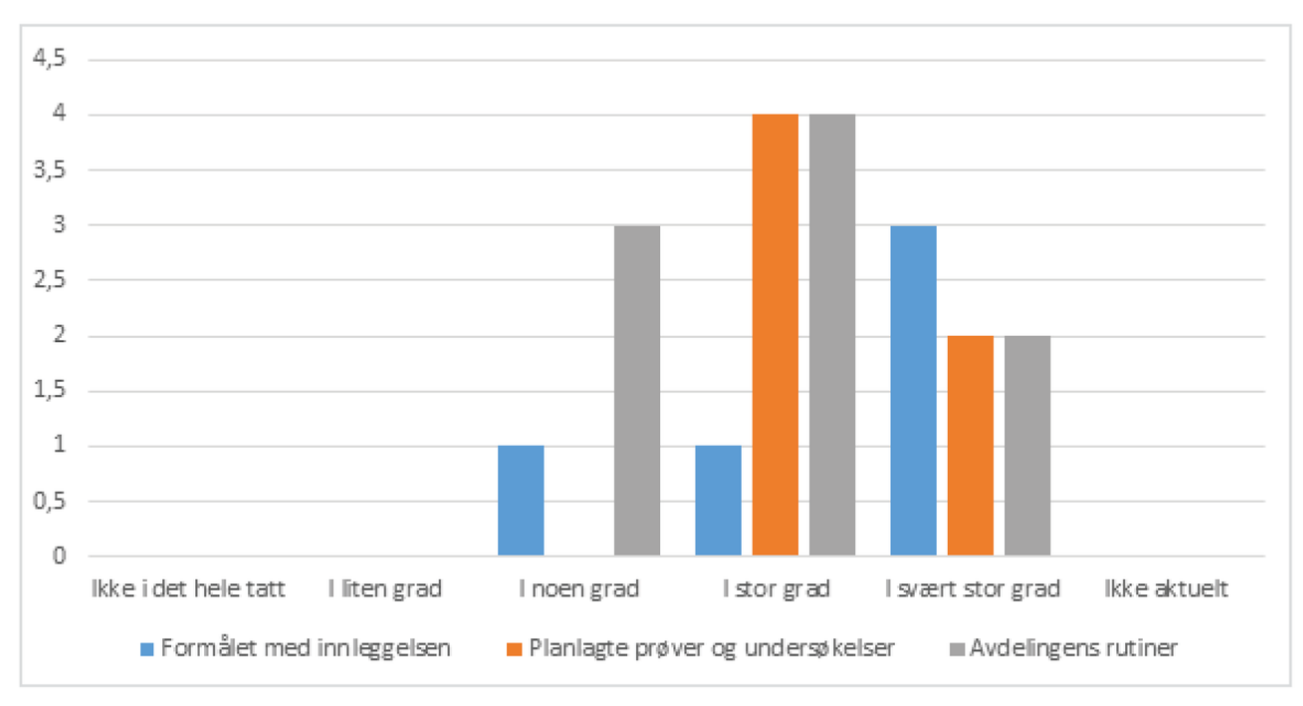

Svarene på spørsmålet om hvorvidt sykepleierne fikk innhentet opplysninger om pasientens helsestatus, allergier, medisiner og eventuelle behov for spesialkost, varierte noe mer (figur 2).

Figur 2: Innhenting av informasjon

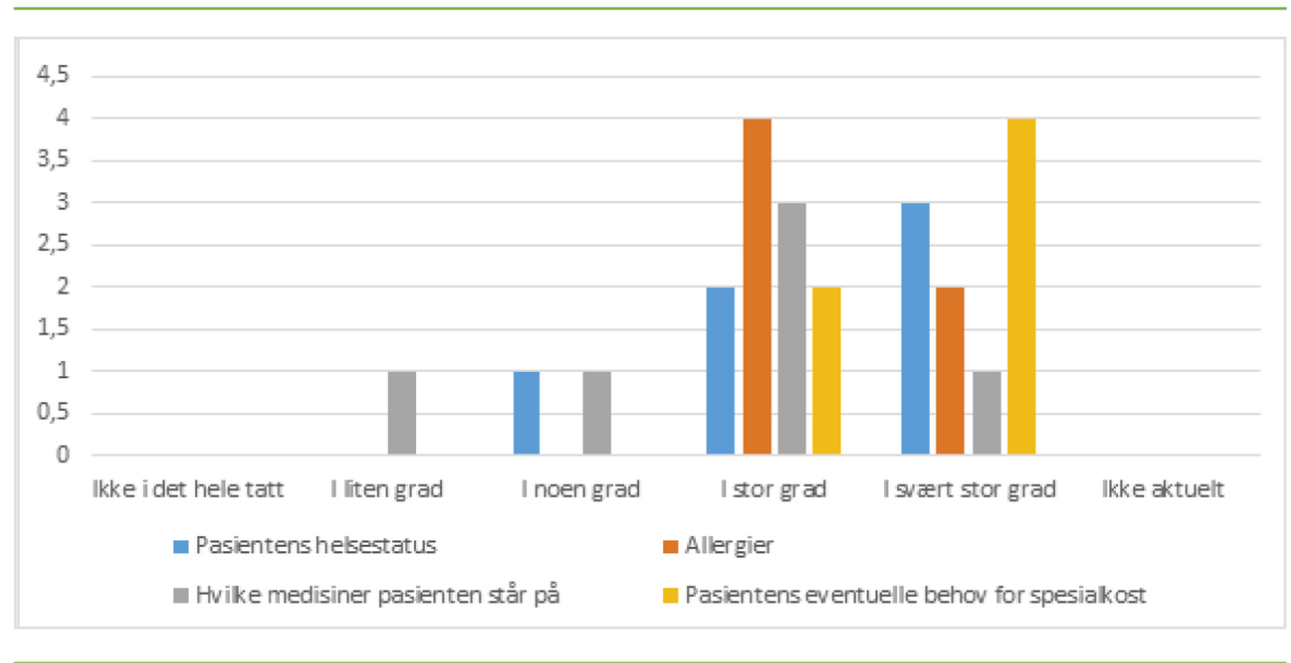

Figur 3 illustrerer at sykepleierne jevnt over opplevde at pasientene var blitt mer involvert i sin egen behandling, og at kvaliteten på sykepleien ble bedre etter at «fast-track»forløpet ble innført. Figuren illustrerer også at sykepleierne opplevde at de hadde tilstrekkelig faglig kompetanse til å gjennomføre egne presamtaler. 


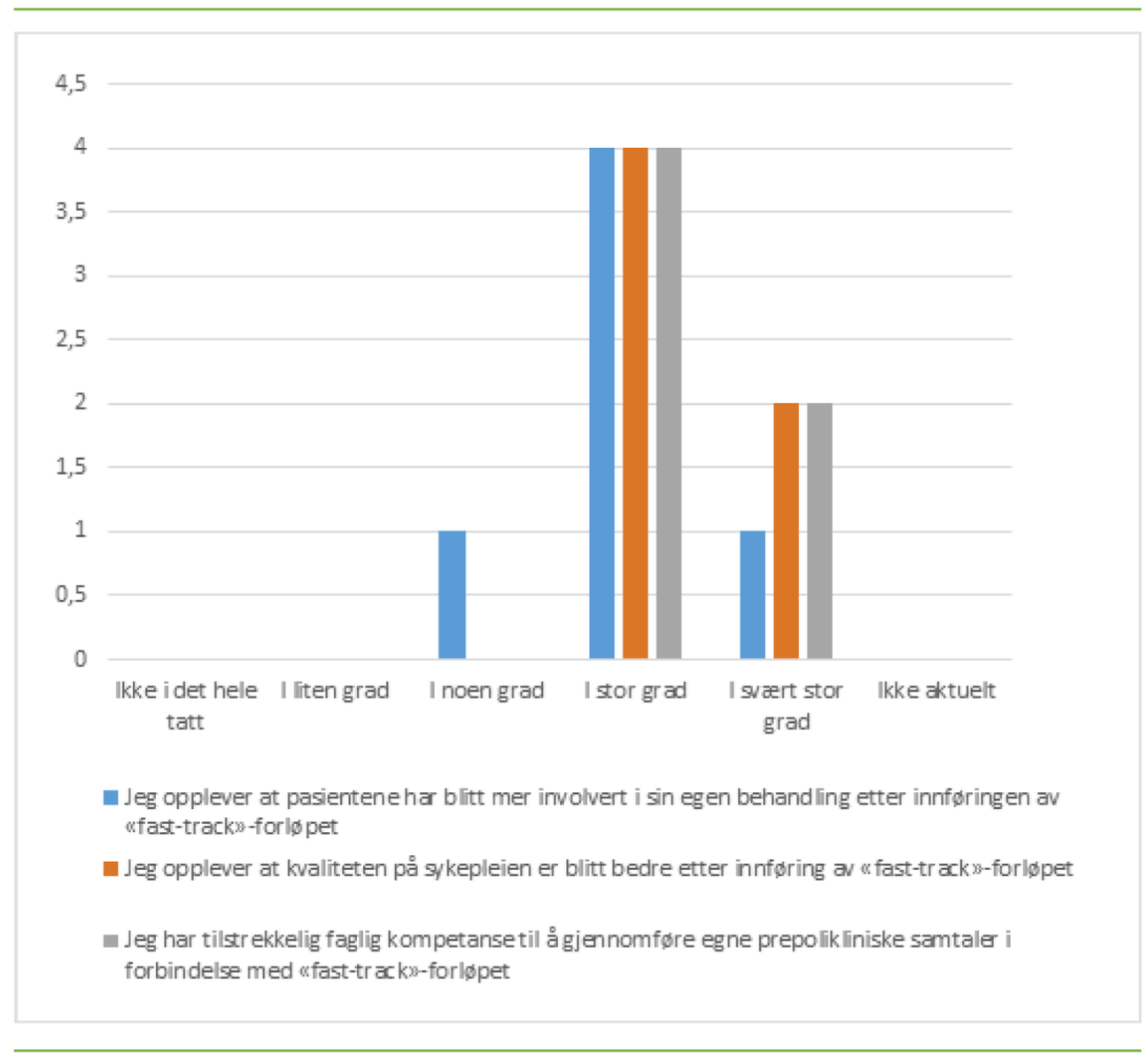

\section{Diskusjon}

Resultatene viser at sykepleierne stort sett fikk innhentet nødvendig informasjon fra pasienten i løpet av presamtalen. Når det gjaldt spørsmålet om hvilke medisiner pasienten brukte, varierte svarene noe mer.

Spørreskjemaet ga ikke svar på hvorfor informasjon om pasientens medisiner ikke alltid var mulig å fă tak i, og det kan være flere mulige forklaringer på dette. Det kan hende at pasientene ikke husket hvilke medisiner de sto på, og at de hadde glemt å få en oppdatert medisinliste fra fastlegen.

I dag har sykehuset tilgang til pasientens kjernejournal og ereseptmodul, noe som gjør det enklere å ha oversikt. Da denne studien ble gjennomført, fantes det ingen felles oversikt over hvilke medisiner de enkelte pasientene brukte. Da var det viktig at pasientene alltid hadde med seg en oppdatert medisinliste (8). Medisinlisten er spesielt viktig hvis pasienten har kontakt med flere leger, og når pasienten skal behandles på sykehus $(3,4)$. 


\section{Pasientmedvirkning}

Sykepleiernes inntrykk var at pasientene ble mer involvert i egen behandling etter at avdelingen innførte «fast-track»forløpet. Å ha innflytelse på og ta del i beslutninger om sykdom og behandling viser seg å være viktig for pasientenes opplevelse av å delta aktivt i egen behandling (9). En god dialog mellom sykepleieren og pasienten innebærer refleksjon, diskusjon og støtte til å ta beslutninger.

Sykepleierens rolle er å støtte pasienten slik at han eller hun kan medvirke i behandlingsprosessen (10). Det er viktig at pasienten har tilstrekkelig med informasjon, slik at vedkommende kan ta egne beslutninger som har betydning for sykdommen, behandlingen og daglige aktiviteter (11).

\section{$\equiv$ ¿Sykepleierens rolle er å støtte pasienten slik at han eller hun kan medvirke i behandlingsprosessen.»}

Sykepleierens kompetanse og ferdigheter blir også viktige i denne sammenhengen. Forskning viser at det er en positiv sammenheng mellom pasientenes trygghet og sykepleierens kompetanse, praktiske ferdigheter og undervisningsferdigheter (12).

\section{Rolle i endring}

Sykepleierens rolle og funksjon er i stadig endring. Innen det revmatologiske fagfeltet har også mange sykepleiere fått et utvidet ansvarsområde, noe pasientene setter pris på $(9,13)$. Sykepleiernes kompetanse og ferdigheter er viktige faktorer $i$ den helhetlige omsorgen.

En del pasienter sier at det er lettere å kommunisere med sykepleierne enn eksempelvis legen (9). God informasjonsflyt mellom pasienten og behandlerne er essensielt i behandlingsforløpet og innvirker på pasientens tilfredshet med oppfølgingen (2).

\section{三 «Sykepleieren så ikke pasienten bare som en diagnose, men som et helt menneske.»}

Pasienttilfredshet er også ansett som en viktig indikator på kvaliteten av behandlingen (13). Et annet viktig moment i denne sammenhengen er pasientens opplevelse av trygghet. 
Forskning viser at sykepleiernes fleksibilitet og tilgjengelighet, eksempelvis på telefon, hadde en positiv innvirkning på pasientenes følelse av trygghet (9). Pasientene uttrykte også at sykepleierne og revmatologene utfylte hverandre. Sykepleieren så ikke pasienten bare som en diagnose, men som et helt menneske.

\section{Pasienttilfredshet}

Et av målene med behandlingsforløpet «fast-track»-inspirert revmatologi var å gjøre pasientene mer forberedt på innleggelsen og $\varnothing \mathrm{ke}$ pasienttilfredsheten (2).

Andre momenter som har vist seg å påvirke pasientenes tilfredshet med sykepleien, har vært hvor godt sykepleierne har satt seg inn i pasientenes sykdomshistorie, nåværende situasjon samt evnen til å formidle kunnskap, støtte og tillit (12). Pasienttilfredshet henger også sammen med forventninger og i hvilken grad pasientenes forventninger blir innfridd $(3,4)$.

Presamtalen i denne studien ga sykepleierne mulighet til både å gi og innhente nødvendig informasjon. Resultatene viste at sykepleierne i stor eller svært stor grad følte at de fikk gitt nødvendig informasjon til pasienten om formålet med innleggelsen, planlagte prøver og unders $\varnothing$ kelser, avdelingens rutiner og pasientens helsestatus.

\section{Konklusjon}

Unders $\varnothing$ kelsen vår viser at sykepleiere som har egne presamtaler med pasienter som planlegges innlagt ved Revmatologisk avdeling, opplevde at de fikk avklart pasientenes forventninger til oppholdet. De fikk gitt nødvendig informasjon om hvorfor pasienten skulle legges inn, og hvilke prøver og unders $\varnothing$ kelser som var planlagt.

Sykepleiernes inntrykk var også at «fast-track»-forløpet medførte at pasientene ble mer involvert og delaktige i sin egen behandling. Sykepleierne opplevde derimot at de ikke alltid fikk innhentet tilstrekkelig informasjon om hvilke medisiner pasienten brukte.

\section{Referanser}

1. Kehlet H, Wilmore DW. (2008). Evidence-based surgical care and the evolution of fast-track surgery. Ann Surg. 2008;248(2):189-98. 
2. Grønning K. Fast-track inspirert Revmatologi ved St. Olavs Hospital. Norsk Rheumabulletin 2014;2:14-5.

3. Almås H, Stubberud D-G, Grønseth R, Toverud C. Klinisk sykepleie 1. Oslo: Gyldendal Akademisk; 2016.

4. Almås H, Stubberud D-G, Grønseth R, Toverud C. Klinisk sykepleie 2. Oslo: Gyldendal Akademisk; 2016.

5. Grønning K, Rodevand E, Steinsbekk A. Paid work is associated with improved health-related quality of life in patients with rheumatoid arthritis. Clin Rheumatol 2010;29:1317-22.

6. Lov 2. juli $1999 \mathrm{nr} .64$ om helsepersonell (helsepersonelloven). Tilgjengelig fra: https://lovdata.no/dokument/NL/lov/1999-07-02-64(nedlastet 20.11.2017).

7. Lov 2. juli 1999 nr. 63 om pasient- og brukerrettigheter (pasient- og brukerrettighetsloven). Tilgjengelig fra: https://lovdata.no/dokument/NL/lov/1999-07-02-63 (nedlastet 20.11.2017).

8. Legemiddelverket. Har du liste over medisinene dine? 2015. Tilgjengelig fra: https://helsenorge.no/legemidler/eldreog-legemidler/medisinliste(nedlastet 20.11.2017).

9. Larsson I, Bergman S, Fridlund B, Arvidsson B. Patients' experiences of a nurse-led rheumatology clinic in Sweden: a qualitative study. Nurs Health Sci 2012;14:501-7.

10. Oliver SM. The role of the clinical nurse specialist in the assessment and management of biologic therapies. Musculoskeletal Care 2011;9:54-62.

11. Arvidsson SB, Petersson A, Nilsson I, Andersson B, Arvidsson B et al. A nurse-led rheumatology clinic's impact on empowering patients with rheumatoid arthritis: A qualitative study. Nurs Health Sci 2006;8:133-9.

12. Bala SV, Samuelson K, Hagell P, Svensson B, Fridlund B et al. The experience of care at nurse-led rheumatology clinics. Musculoskeletal Care 2012;10:202-11. 
13. Koksvik HS, Hagen KB, Rødevand E, Mowinckel P, Kvien

$\mathrm{T}$ et al. Patient satisfaction with nursing consultations in a rheumatology outpatient clinic: a 21-month randomised controlled trial in patients with inflammatory arthritides. Ann Rheum Dis 2013;72:836-43. 